\title{
SOCIO-DEMOGRAPHIC DETERMINANTS OF CREDIT RATIONING AT BAITUL MAAL WA TAMWIL IN INDONESIA
}

\author{
Permata Wulandari ${ }^{1}$ and Salina Kassim ${ }^{2}$ \\ ${ }^{1}$ Universitas Indonesia, Indonesia, permata.w@gmail.com \\ ${ }^{2}$ IIUM Institute of Islamic Banking and Finance, Malaysia, ksalina@iium.edu.my
}

\begin{abstract}
This study seeks to identify credit rationing socio-demographic determinants to Islamic microfinance to achieve welfare improving goals in three Bottom of the Economic Pyramid (BOP) regions: Yogyakarta, East Lombok and Makassar, South Sulawesi, Indonesia. Another primary focus of this study is to highlight the suggested solutions from Islamic microfinance practitioners to overcome the challenges in the practice of credit rationing assessment. 2,650 borrowers at the BOP in 26 Islamic Microfinance Institutions (MFIs) in Indonesia were selected based on cluster sampling and purposive sampling methods. A questionnaire is adapted from several previous studies. Multinomial logistics regression is used in this paper. Results show that the determinant of credit rationing based on socio-demographic factors, reflecting certain socio-demographic factors that include age, gender, account balance, dependents, salary, monthly income, formal education, access to financing facility in the previous year, distance, and years of saving, has significant influence on the probability of getting financing. Thus, in order to reduce the credit-rationing problem, the major implications from this study are that Baitul Maal wa Tamwil (BMT) should enhance the participation of women, using monthly income rather than salary determinants, provide credit plus financing and realize a one village one BMT program. The solutions would enhance the participation of BOP borrowers at BMT.
\end{abstract}

Keywords: Socio-demographic, Credit Rationing, BOP, BMT.

JEL Classifications: E50; G21; H81.

Article history:

Received : December 10, 2018

Revised : : September 16, 2019

Accepted : October 22, 2019

Available online : November 1, 2019

https://doi.org/10.21098/jimf.v5i3.1156 


\section{INTRODUCTION}

The issue of misplacement of to the targeted segment of the society, particularly to those at the bottom of the economic pyramid (BOP) is one of the major issues in microfinance. The lack of economic activity among the poor borrowers is a significant barrier to microcredit accessibility, resulting in the poor being unable to attain a stable source of income. Such conditions suggest that when several individuals want to access a microfinance facility, they cannot do so because they face the credit rationing problem (Shankar, 2013). In addition, the problems not only occur in small MFIs, but also in successful micro-credit programs, such as Grameen Bank, in which borrowers sometimes face the issue of limited accessibility to credit (Vasimalai and Narender, 2007).

Therefore, this study will discuss socio-demographic determinants of credit rationing. Specific factors in the socio-demographic determinants of credit rationing include gender (Vitor et al., 2014; Cheng and Ahmed, 2014; Fletschner, 2009; Chiu et al., 2014; Menkhoff and Rungruxsirivorn, 2011; Mijid and Bernasek, 2013; Zeller, 1994), income (Duca and Rosenthal, 1991; Zeller, 1994), distance (Zeller, 1994), financing duration (Carling and Lundberg, 2005; Ferri and Murro, 2014), savings duration (Vitor et al., 2014; Dusuki, 2008), education level (Al-Azzam, Hill, and Sarangi, 2012; Duong and Izumida, 2002; Menkhoff and Rungruxsirivorn, 2011), marital status (Cheng and Ahmed, 2014; Papias and Ganesan, 2010), dependency (Duong and Izumida, 2002; Zeller, 1994) and whether or not the head of household is the credit applicant (Duong and Izumida, 2002; Mason, 2014; Togba, 2012).

In fact, the lowest income groups face more complex problems of credit rationing than higher income groups despite the fact that microcredit programs are designed to target households at the BOP (Khoi et al., 2013). Although credit rationing is not necessarily the source of the poverty trap, it reinforces the occurrences of the poverty trap. People at BOP who face credit-rationing problems will find it difficult to meet their daily needs because they have no income. The cheap credit policy of the governments in numerous developing countries is generally not effective (Jia, Heidhues, and Zeller, 2010). The compromise rate on margin discourages savings, distorts factor prices and fails in the proper substitution of labor for land and capital, paralyzes institutional lenders and excludes those at the BOP, particularly the poor and small farmers.

Furthermore, the issues of credit rationing mentioned earlier are also prevalent in the practice of Islamic microfinance in Indonesia. Approximately 28.07 million people, or $11.37 \%$ of the total Indonesian population, are categorized as those in the BOP, having an average monthly income of around US\$24 per month or less, based on Indonesia Central Bureau of Statistics (Badan Pusat Statistik, 2014). Such a condition is reflected not only in terms of minimum income, but also lack of education, lack of accessibility to clean water, health provisions, and proper sanitation (Rokhman, 2013).

In the specific case of Indonesia, an issue of minimum participation of borrowers in Indonesia's formal financial institutions often appears. For instance, in 2014 the percentage of accounts at formal financial institutions for customers aged more than 15 years old was only $36 \%$ of the total population, compared to $20 \%$ in 2011. Many borrowers preferred borrowing from other channels, such as from friends and relatives, up to $41 \%$ in 2014 . As a result, the data suggest that the majority of people at the BOP still faced credit rationing problems because 
they prefer to borrow from informal sources than formal sources. According to Turvey et al. (2010), one of the major reasons why many people choose friends and relatives as a source of funding rather than other informal funding alternatives in Indonesia is because other sources, such as loan sharks, impose high interest rate, which is forbidden in Islamic practice.

In dealing with this problem, the Islamic MFIs must conduct proper identification of credit rationing determinants in that people at the BOP would have ample accessibility to financing. The specific research objective (RO) of this study is to analyze factors determining credit rationing to Muslims at the BOP in the BMT in Indonesia. The contribution of measuring credit-rationing determinants in Indonesia Islamic microfinance will allow lenders to know how to screen and assess the risk of the client. This study also provides significant information on the factors that need to be considered as important in an attempt to reduce the problems of credit rationing by BMT. The results of this study could improve access to the required amount of credit in Islamic MFI. The information would also help stakeholders in the Islamic MFI sectors to improve access to credit from BMT. This study also provides socio-demographic characteristics in predicting the financing amount received in Indonesia. It is important to know socio-demographic determinants, which influence credit rationing. If socio-demographic information about Islamic MFI borrowers were a useful means of screening, borrowers' ability to pay would be related to variation in loan size (Mason, 2014).

\section{LITERATURE REVIEW}

\subsection{Background Theory}

\subsubsection{Theory of Credit Rationing}

A simple definition of credit rationing signifies an occasion when borrowers demanded more credit amount than the factual credit they received (Ferri and Murro, 2014). Credit rationing is also referred to as a condition in which individuals who need credit are not able to apply for the credit or applicants are not offered the desired amount they applied for (Vitor et al., 2014).

Further, credit rationing is also reflected in a condition where borrowers propose a specified amount of funding, but lenders could either totally reject or partially reject their requests (Jia, Heidhues, and Zeller, 2010). Accordingly, people who apply for financing face one of two possible outcomes: either the financing application is fully granted or rejected. Two types of rejection include (1) a complete rejection where applicants do not get any financing at all, and (2) a partial rejection where borrowers propose a funding amount but only partially granted. Ultimately such applicants who are discouraged, completely rejected, or partially rationed fall under the category of the credit rationing condition.

The problem of credit rationing occurs when lenders increase interest rates or supply a smaller loan amount than what is demanded. This practice, however, is not limited only to the interest rate ceiling and the gap between supply and demand. In addition, the relationship between borrowers and lenders plays an important role in this situation. In practice, honest borrowers only accept a loan contract that they expect to repay; whereas, dishonest borrowers default on loans at whatever the cost of default (Jaffee and Russell, 1976). The concept of credit rationing has been developed by Stiglitz and Weiss (1981) who stated that: 
"Why is credit rationed? Perhaps the most basic tenet of economics is that market equilibrium entails supply equaling demand; that if demand should exceed supply, price will rise, decreasing demand and/or increasing supply until demand and supply are equated at the new equilibrium price. So if prices do their job, rationing should not exist." Consequently, credit rationing initially occurs when demand for funding is greater than supply. For instance, potential borrowers who are rejected by a bank tend to not be able to get funding even if they indicate that they want to pay more or possess high value collateral, which could be due to increased risk of the bank's loan portfolio (Stiglitz and Weiss, 1981). Under such a condition, the equaling of supply and demand of loanable funds will not be achieved, and credit restriction and rationing will occur.

The issue of asymmetric information is the main reason behind the existence of the credit rationing condition. Asymmetric information occurs when lenders have no adequate information about potential borrowers (de Meza and Webb, 2000). Because of asymmetric information, certain borrowers are unable to obtain loans at any rates even though there is an ample supply of credit (Dubofsky, 1985).

\subsubsection{Socio-Demographic Determinants of Credit Rationing: at Glance}

Several socio-demographic factors act as determinants and influence credit rationing. Zeller (1994) conducted a study on the determinants of loan rationing by formal and informal lenders. Based on longitudinal research of 189 random households in ten villages in three agro-ecological regions in Madagascar, the study found that the determinants used by formal and informal lenders are the same in terms of obtaining and using information about the creditworthiness of the credit applicants. The informal and formal lenders' decisions to approve a loan request were based on the applicants' household income and debt as an indicator of repayment ability. Poor and medium-income households had to pay higher interest rates than the rich households did even though the poor households had a better record of debt repayment than their richer counterparts did. Such a practice implies that people at the BOP are treated as untrustworthy and, therefore, categorized as risky borrowers.

Moreover, Mason (2014) found that individual characteristics such as gender and age play important roles in the incidence of credit rationing. Although being a woman is not a significant predictor of credit rationing, it is strongly associated with receiving smaller loans than men receive. Poorer households and households with heads of an older age are more likely to apply for loans from informal sources (Simtowe et al., 2008), which is due to the perceived higher risks associated with poorer and older borrowers. Social network and family relations remain important for access to informal loans. A negative relation between age and demand may also be reflected in the complexity of the loan application and approval procedures for formal and microfinance loans.

\subsection{Previous Studies}

Based on the literature review, a variation based on conceptual and empirical testing occurs among rural clients of the credit market, which due to different geographical contexts and socio-demographic set-ups as well as in different 


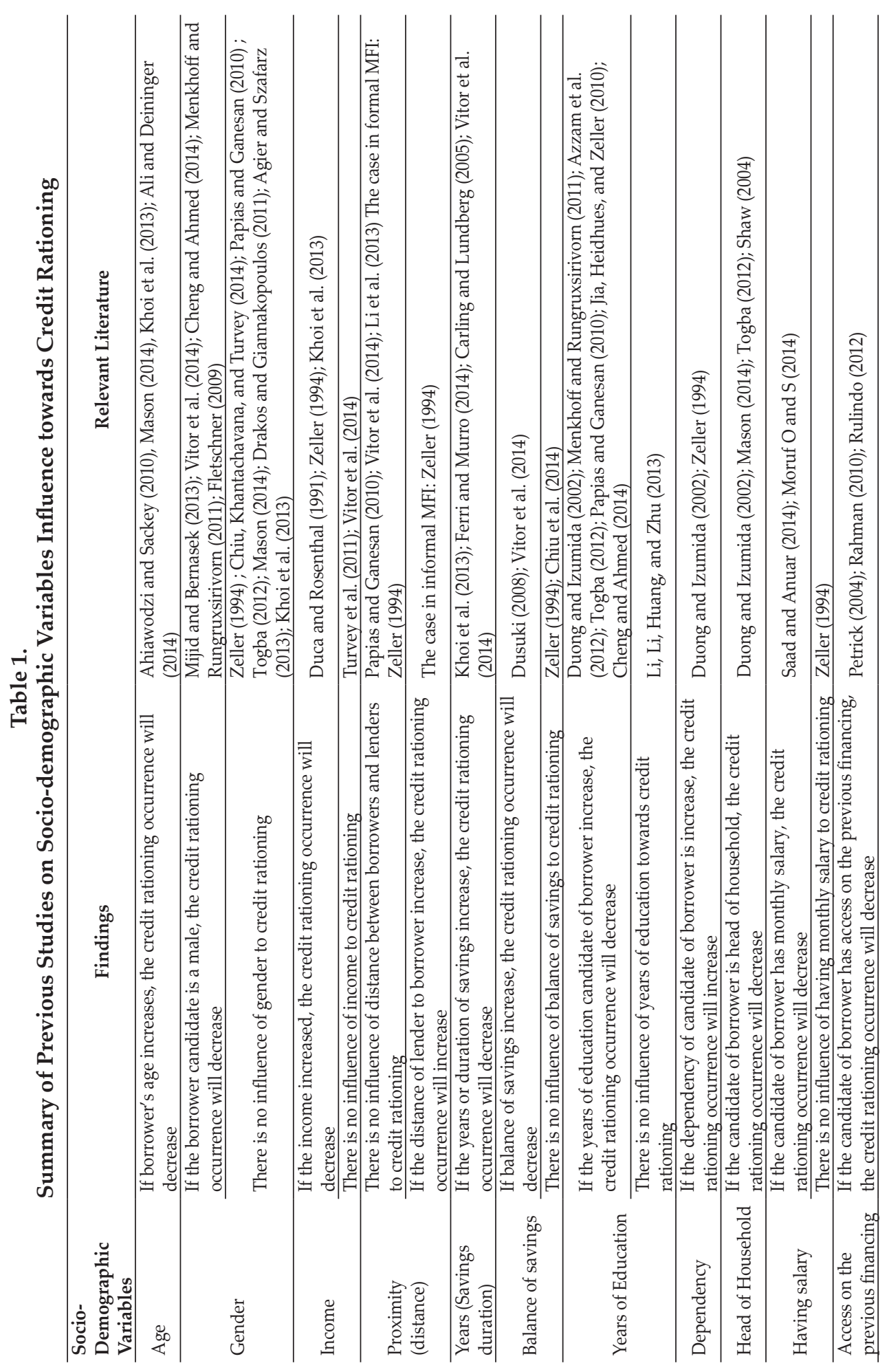


business, economic and financial environments. Table 1 summarizes the literature on socio-demographic variables influencing credit rationing.

\section{METHODOLOGY}

\subsection{Data}

A five-step procedure of sampling to minimize potential sampling errors based on Malhotra's method (Malhotra, 1999) was used in this research:

1. Defining target population;

2. Determining the sampling frame;

3. Selecting the sampling technique;

4. Determining the sample size; and

5. Executing the sampling process.

The population and samples in this study were divided into two based on quantitative and qualitative approaches. Quantitatively, the population in this study is the group of poor Muslim who applies or intended to apply for financing in West Nusa Tenggara Barat, Yogyakarta, and South Sulawesi. The samples reflect the three highest numbers of poor people and the regions with the lowest poverty line level. Other criteria are based on where BMT are established.

Moreover, the samples were selected from percentage of BOP to total population in a region and not based on the real BOP population because the percentage of BOP to total population represented the real BOP condition than BOP population. The criteria for sample size is non-bias and data representative. Cluster sampling is selected in this study. Based on Krejcie and Morgan (1970), 387 samples are adequate for a population of 1 million. Table 2 shows the region and samples:

Table 2.

Region and Samples

\begin{tabular}{lccccc}
\hline No & Region & $\begin{array}{c}\text { Real BOP } \\
\text { Population }\end{array}$ & $\begin{array}{c}\text { Total BMT } \\
\text { Existence } \\
\text { (Central BMT } \\
\text { Data) }\end{array}$ & Sample & $\begin{array}{c}\text { Total } \\
\text { Sample }\end{array}$ \\
\cline { 1 - 5 } 1 & Sulawesi Selatan & 1.085 .800 & 29 & 1004 & \\
\cline { 1 - 5 } 2 & Nusa Tenggara Barat & 816.620 & 10 & 461 & \\
\hline 3 & Daerah Istimewa Yogyakarta & 532.590 & 40 & 1185 & \\
\hline Total & & & & & 2,650 \\
\hline
\end{tabular}

Moreover, the sampling requirements for quantitative analysis are:

1. Muslims at the BOP who had lower financing nominal (under IDR10,000,000);

2. Members of BMT for more than one year;

3. Were married;

4. Had a child/children; and

5. Had lived in Nusa Tenggara Barat or DI Yogyakarta or Sulawesi Selatan for more than one year. 


\subsection{Model Development}

In order to analyze factors determining credit rationing to Muslims at the BOP in the semi-formal Islamic MFIs in Indonesia, the following variables are considered.

\section{i. Dependent Variable: Credit Rationing}

A condition in which the lender rations credit and borrowers cannot obtain the amount of credit, which they desire. This will serve as the dependent variable, which is defined as partially satisfied (not fully granted), completely rejected (no financing granted) and fully satisfied (fully granted financing) (Vitor et al., 2014).

\section{ii. Independent Variables}

Socio-demographic determinants include age, gender, proximity (distance to Islamic MFI), years of savings, balance of savings, number of dependents, head of household, having salary, income, years of formal education, and access to previous financing.

Age: A person of the productive age has a greater chance of getting the amount of loan he requires. Old and young tend to demand a smaller amount of loan because the formal sector thinks that they only increase costs of transactions (Ahiawodzi and Sackey, 2010). This is consistent with the idea that the younger borrowers have higher possibility of default because they have no stable sources of income, while older age persons are associated with high risk of repayment especially those who are in the pension age. Age indicates earning capacity (Mason, 2014). Age will increase the probability of access to microfinance because older people are believed to accumulate more wealth and can control their resources (Khoi et al., 2013). Age also serves as a proxy for accountability and commitment to repay the loan.

Gender: In the microfinance literature, the male group is recognized as those who have greater access to credit compared with female especially in banks or formal microfinance institutions (Mijid and Bernasek, 2013; Vitor et al., 2014). The same case also occurs in rural credit cooperatives where males have greater access than woman does (Cheng and Ahmed, 2014; Fletschner, 2009). The reason is that women have no experience related to income generating activities, in that they are expected to face difficulty in repaying a financing given by the MFIs (Fletschner, 2009). Consequently, they face higher credit rationing. Many Islamic MFIs are now focused to provide funding to woman in order to enhance the participation of woman.

Proximity (Distance to Islamic MFI): People at the BOP who live nearer to the Islamic MFI have easier access to financing. Proximity is projected to reduce the probability of borrowers being rationed (Carling and Lundberg, 2005). Based on the literature, a distance of two kilometers or less is the standard distance of acceptance which is measured only by walking distance that does not require the need to take public transportation that would incur cost (Vitor et al., 2014). The MFI would also face greater risk when they provide funding to distant borrowers (Carling and Lundberg, 2005). 
Years of savings: Years of savings is used as a proxy of consumer loyalty and trust in microfinance (Vitor et al., 2014). It can be measured by the number of years that the borrowers have been saving with the MFIs. The longer the years of savings with the MFIs, the lower the probability of credit being rationed (Zeller, 1994). This is because the years of savings prove the creditworthiness of the borrowers and will decrease the credit rationing occurrence (Chiu et al., 2014).

Balance of savings: The more balance of savings with the MFI means the more access to financing because savings can be considered as collateral. A borrower with a positive balance in his/her bank account has a higher probability of securing a loan in full (Vitor et al., 2014). This can increase their creditworthiness (Dusuki, 2008; Vitor et al., 2014). Since a balance of savings serves as collateral, credit rationing will be reduced as the balance increase (Vitor et al., 2014).

Number of dependents: While generally a dependent is defined as someone who requires financial or other support, in the context of this study dependents were children under 13 years old or younger who are under the care of a person (Vitor et al., 2014). In general, the BOP family with many dependents is not likely even to be able to feed itself (Bao Duong and Izumida, 2002). As a consequence, the more number of dependents, the more credit rationing occurrence (Zeller, 1994).

Head of household: A head of household is defined as a person who is responsible to their family. If the borrower candidate is the head of a household, she or he usually has a lower problem of credit rationing since he or she also act as the main breadwinner (Mason, 2014; Togba, 2012). Moreover, a married female household heads also appear to have more financial freedom than single one (Shaw, 2004).

Having salary: Having salary is not a determinant of credit rationing in informal and formal credit groups since many borrowers work in the informal sector which is characterized by unstable income (Zeller, 1994). However, having no salary indicates a failure of getting micro personal loan because of bad qualification (Saad and Anuar, 2014). A higher salary will enhance the standard of living (Moruf O and Oyedele K, 2014).

Income: Source of income is an important factor in credit rationing. If the income increases, credit rationing will decrease (Duca and Rosenthal, 1991; Zeller, 1994; Khoi et al., 2013). According to Mirghani et al. (2011), the common sources of income for Muslims at the BOP come from their work in small medium enterprises (SMEs). Islamic MFI should enhance the ability to reach consumers by supporting the SMEs because most of people at BOP have sources of income that come from the SME (Fararah and Al-Swidi, 2013).

Years of formal education: The more educated the person is, the easier it is for him or her to get financing, thus the lesser the incidence of credit constraint. Level of education is a proxy for how well a person can handle the problems of credit rationing because the more educated would have more knowledge about how to get financing granted (Duong and Izumida, 2002; Menkhoff and Rungruxsirivorn, 2011; Azzam et al., 2012; Togba, 2012; Papias and Ganesan, 2010; Jia, Heidhues, and Zeller, 2010; Cheng and Ahmed 2014).

Access to previous financing: Having access to previous financing increases the reputation of borrowers especially those who have previous punctual repayment of loans records (Petrick, 2004). In practice, Islamic microfinance only provides financing if the previous financing has been repaid (Rahman, 2010). Murabaha and 
musharakah are rarely given to first time clients. They are usually given to clients who have had access to previous financing and showed good repayment record (Rulindo, 2012).

The summary of socio-demographic variables influencing credit rationing is shown in Table 3 below:

Table 3.

Summary of Socio-demographic Variables Influences to Credit Rationing

\begin{tabular}{|c|c|}
\hline $\begin{array}{l}\text { Socio-demographic } \\
\text { Variables }\end{array}$ & Relevant Literature \\
\hline Age & $\begin{array}{l}\text { (-)(Ahiawodzi and Sackey, 2010), (-)(Mason, 2014), (-)(Khoi et al., 2013), (-) } \\
\text { (Ali and Deininger, 2014) }\end{array}$ \\
\hline $\begin{array}{l}\text { Gender }(1=\text { male }) \\
(0=\text { female })\end{array}$ & $\begin{array}{l}\text { (-)(Mijid and Bernasek, 2013), (-)(Vitor et al., 2014), }(-)(\text { Cheng and Ahmed, } \\
\text { 2014),(-)(Menkhoff and Rungruxsirivorn, 2011), }(-)(\text { Fletschner, 2009), }(\neq) \\
(\text { Zeller, 1994), }(\neq)(\text { Chiu, Khantachavana, and Turvey, 2014), }(\neq)(\text { Papias } \\
\text { and Ganesan, 2010), }(\neq)(\text { Togba, 2012), }(\neq)(\text { Mason, 2014), }(\neq)(\text { Drakos and } \\
\text { Giannakopoulos, 2011), }(\neq)(\text { Agier and Szafarz, 2013), }(\neq)(\text { Khoi et al., 2013) }\end{array}$ \\
\hline Having salary & $(\neq)($ Zeller, 1994), $(-)($ Saad and Anuar, 2014), (-)(Moruf O and S, 2014) \\
\hline Income & $\begin{array}{l}\text { (-)(Duca and Rosenthal, 1991), (-)(Zeller, 1994) (-)(Khoi et al., 2013), }(\neq) \\
\text { (Turvey et al., 2011), }(\neq)(\text { Vitor et al., 2014) }\end{array}$ \\
\hline Proximity (distance) & $\begin{array}{l}(\neq)(\text { Papias and Ganesan, 2010), }(\neq)(\text { Vitor et al., 2014), }(\neq)(\text { Carling and } \\
\text { Lundberg, 2005), formal MFI }(\neq)(\text { Zeller, 1994), Informal MFI }(+)(\text { Zeller, 1994) }\end{array}$ \\
\hline Years of savings & $\begin{array}{l}\text { (-)(Khoi et al., 2013), (-)(Ferri and Murro, 2014), (-)(Carling and Lundberg, } \\
\text { 2005), (-)(Vitor et al., 2014) }\end{array}$ \\
\hline Savings amount & $(-)($ Dusuki, 2008), $(-)($ Vitor et al., 2014), $(\neq)($ Zeller, 1994), $(\neq)($ Chiu et al., 2014) \\
\hline $\begin{array}{l}\text { Year(s) of Formal } \\
\text { Education }\end{array}$ & $\begin{array}{l}\text { (-)(Duong and Izumida, 2002), (-)(Menkhoff and Rungruxsirivorn, 2011), (-) } \\
\text { (Azzam et al., 2012), (-)(Togba, 2012), (-)(Papias and Ganesan, 2010), (-)(Jia, } \\
\text { Heidhues, and Zeller, 2010), (-)(Cheng and Ahmed, 2014) }(\neq)(\text { Cheng and } \\
\text { Ahmed, 2014) }\end{array}$ \\
\hline Dependency & $(+)($ Bao Duong and Izumida, 2002), (+)(Zeller, 1994) \\
\hline Head of household & $\begin{array}{l}\text { (-)(Bao Duong and Izumida, 2002), (-)(Mason, 2014), (-)(Togba, 2012), (-) } \\
\text { (Shaw, 2004) }\end{array}$ \\
\hline $\begin{array}{l}\text { Access on the previous } \\
\text { financing }\end{array}$ & (-)(Petrick, 2004), (-)(Rahman, 2010), (-)(Rulindo, 2012) \\
\hline
\end{tabular}

Notes: (-) indicates having negative influence to credit rationing, $\left(_{+}^{+}\right.$indicates having positive influence to credit rationing, $(\neq)$ indicates having no influence to credit rationing

Eleven hypotheses are formulated to analyze the socio-demographic determinants of credit rationing:

(i) Older people have negative influence on credit rationing occurrence;

(ii) Men have more negative influence on credit rationing occurrence than women;

(iii) Having a salary has no influence on credit rationing occurrence;

(iv) Higher income has negative influence on credit rationing occurrence;

(v) Proximity has no influence on credit rationing occurrence;

(vi) Years of savings has negative influence on credit rationing occurrence;

(vii) Positive balance of savings has negative influence on credit rationing occurrence; 
(viii) Years of formal education has negative influence on credit rationing occurrence;

(ix) Number of dependents has positive influence on credit rationing occurrence;

(x) Head of household has negative influence on credit rationing occurrence; and

(xi) Access to previous financing has negative influence on credit rationing occurrence.

The model of credit rationing using demographic analysis is derived from borrowers assessment utility by Vitor et al. (2014). This model is derived from using the credit for current consumption, and next period consumption, using credit for production and capital valuation function when borrower uses the credit to invest. The baseline model is below:

$$
\mathrm{W}_{\mathrm{i}}=\alpha^{\prime} \mathrm{Z}_{\mathrm{i}}+\mu_{\mathrm{i}}
$$

Where,

$W_{i}=$ Borrowers' assessment of utility

$Z_{i}=$ Institutional factors

From equation (1), the lender decides whether to allocate the applicant all the credit applied for, reduce the amount requested or totally reject the application (Vitor et al., 2014; Zeller, 1994). This model will be tested in BMT. There is multinomial logistic model specified as follows:

$$
\begin{aligned}
& \text { CR }_{\mathrm{i}}=\beta_{0}+\beta_{1} \text { AGE }+\beta_{2} \text { GEN }+\beta_{3} \text { SAL }+\beta_{4} \text { INCOME }+\beta_{5} \text { PROXY }+ \\
& \beta_{6} \text { SAVYEAR }+\beta_{7} \text { BALDEPO }+\beta_{8} \text { EDUCYEAR }+\beta_{9} \text { DEPEDENTS }+\beta_{10} \text { HOH }+ \\
& \beta_{11} \text { ACCESS }+\beta_{12} \delta+\mu
\end{aligned}
$$

Where,

$C R_{i}$ : credit rationing as dependent variable. This will be applied to three models:

$C R_{1}$ : a dummy variable with a value of 0 if borrower at $B O P$ is partially satisfied and 1 if the respondents are fully satisfied,

$C R_{2}$ : a dummy variable with a value of 0 if borrower at BOP is completely rejected and 1 if the respondent is fully satisfied,

$\beta_{1} A G E$ : respondent's age

$\beta_{2} G E N$ : a gender, which is a dummy variable and takes a value of 1 if the respondent is male and 0 if female.

$\beta_{3} S A L$ : respondent's salary, which takes a value of 1 if having salary and 0 if not having salary

$\beta_{4} I N C O M E$ : income if individual earn wage income is 1 and 0 if the other.

$\beta_{5} P R O X Y$ : financial services proximity, which is described as poor people who live nearer to microfinance institutions and can be contacted. A dummy variable of value 1 is used when the distance between a Muslim at the BOP and a microfinance institution is between $0-2 \mathrm{~km}$ and 0 otherwise. 
$\beta_{6} S A V Y E A R S$ : length of period of savings, which is the duration of a BOP Muslim's relationship with the financial institution used as a proxy for customer loyalty and trust.

$\beta_{7} B A L D E P O$ : the positive balance on the borrower's account with the financial institution. A dummy variable of value 1 is when the borrower has a positive balance and 0 otherwise.

$\beta_{8}$ EDUCYEAR: number of years of formal education.

$\beta_{9} D E P E D E N T S$ : number of children under 13 years old or younger.

$\beta_{10} \mathrm{HOH}$ : dummy variable if individual is head of household. It will be noted as 1 and otherwise 0 .

$\beta_{11}$ ACCESS: access on previous financing. A dummy variable of value 1 is given when a borrower has had access to previous financing and 0 otherwise.

\subsection{Method}

Logistic regression is used to explain the relationship between a set of covariate or explanatory variables and a dichotomous response variable (Hsieh, $\mathrm{Li}$, and Lee, 2013). Generally, such a regression is well suited for testing and describing the relationships between one or more categorical or continuous predictor variables and a categorical outcome variable (Peng, Lee, and Ingersoll, 2002). The difference between a linear and logistic regression model is reflected in the assumptions and the choice of parametric model (Hosmer and Lemeshow, 2000). Logistic regression can accommodate categorical outcomes that are dichotomous (binary logistic) and polytomous (multinomial logistic). Logit is the log of the odds that an event occurs. Several assumptions of a logistic model based on Hosmer and Lemeshow (2000) include:

a. Normal distribution is no need in logistic regression but should use multivariate normal distribution;

b. The dependent variable should be heterochedastic meaning that there is no homogeneity in the variance assumption;

c. There is no assumption of normally distributed error terms;

d. Independent variables do not require to be interval and unbounded; and

e. A linier relationship between dependent and independent variables is not assumed.

The logistic model equation is as bellow (Mahmood et al., 2014):

$$
\mathrm{P}(\mathrm{Y})=\frac{1}{1+e^{-(a o+\beta 1 X 1+\beta 2 X 2+\cdots+\beta n X n)}}
$$

Where:

i. $\mathrm{P}(\mathrm{Y})$ is the probability of $\mathrm{Y}$ occurring;

ii. e is the base of natural logarithms; and

iii. $\beta n$ is the regression coefficient variable of $\mathrm{Xn}$ 


\section{RESULT AND ANALYSIS}

\subsection{Results}

\subsubsection{Demographic Statisticss}

Of the total 2,760 questionnaires distributed, 2,650 completed questionnaires were returned, representing a $96.01 \%$ response rate. Eight cities in the Daerah Istimewa Yogyakarta had a response rate $98.75 \%$ (1,185 valid questionnaires), 12 cities in South Sulawesi Selatan 95.62\% (1,004 valid questionnaires), and West Tenggara Barat $90.39 \%$ (461 valid questionnaires). The relatively low response rate and low validity of the responses in West Nusa Tenggara Barat was probably because the typology of the region in remote area was difficult to access. The small of population was also the cause of a lower response rate. Table 4 describes the response rate in each province.

2,650 respondents in this analysis comprised 1,006 (37.96\%) male and 1,644 $(62.04 \%)$ female. Table 5 shows that women suffered from the incidence of credit rationing (completely rejected and partially funding) more than men. Having salary and not having salary are equally distributed between 1,236 (46.64\%) and 1,414 (53.36\%). However, it is shown that people who have salary are more completely rejected in financing than those not having salary but this is lower in the case of partially funding.

As many as $740(27.92 \%)$ were respondents with an income under $\$ 100$ per month, 829 (31.28\%) were respondents with income $\$ 100-\$ 150$ and 882 (33.28\%) were respondents with income of $\$ 151-\$ 500$, while only a small percentage had an income above $\$ 500$, which means that most of respondents have a low-income level and can be categorized as people at the bottom of the economic pyramid. In Table 5, people who have lower income tend to suffer credit rationing (completely rejected and partially funding). Similarly, whether or not the respondents are the head of a household signifying the salary indicator reflects a somewhat equal distribution between 1,175 (44.34\%) and 1,475 (55.66\%). Besides, respondents who were not the head of a household had a lower credit rationing than those who were.

Table 5 shows that respondents with fewer generations of the family in the village dominate the number of respondents in this study. Around 1,635 (61.32\% of total respondents) are people with 0 to 3 family generations in the village and 1,025 (38.68\% of total respondents) are those with more than three family generations in the village. Respondents with fewer family generations have a lower incidence of being completely rejected (37\% of total respondents) but a higher incidence of being partially funding (59.14\% of total respondents).

Because of the dominance of those with fewer generation of the family, 1,094 respondents $(41.28 \%)$ had one to three relatives in the village, followed by $819(30.91 \%)$ who had more than three relatives in the village and $737(27.81 \%)$ having no relatives. Respondents who have fewer relatives tend to be completely rejected for funding (45.09\% of total respondents). Meanwhile, the level of education indicator shows that most respondents are having more than 9 years of formal education, 1,175 (44.34\%), and the number of those having 7-9 years formal education is $719(27.13 \%)$; this is followed by those having 1-6 years formal education, 491 (18.53\%), and those having no formal education, around 265 (10\%). This is expected since Indonesia has implemented the requirement for all citizens 


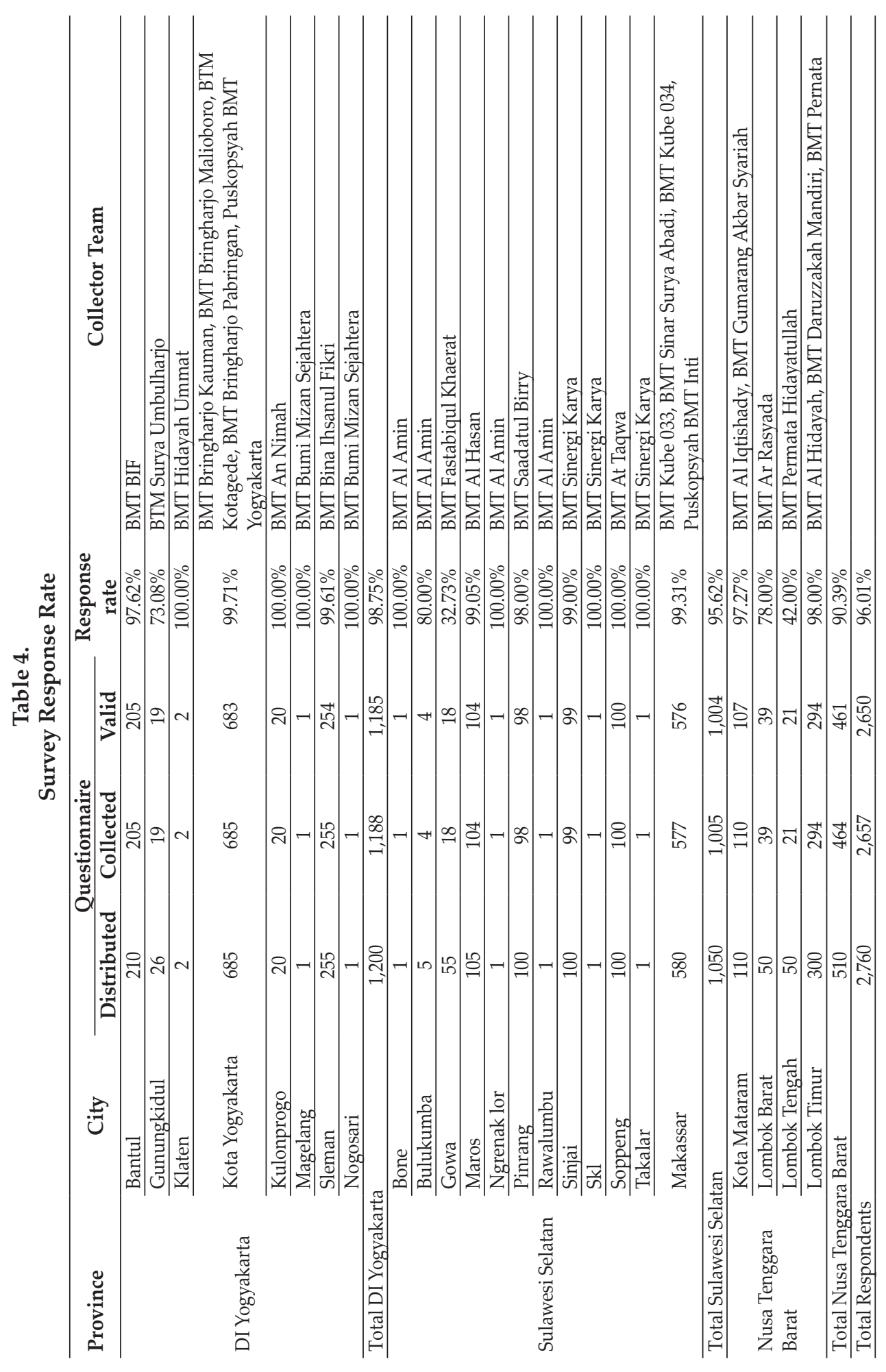


to have at least 9 years of formal education. The more educated the respondents were, the lower the incidence of being completely rejected for funding.

Since the characteristics of most of people at the bottom of the economic pyramid are that they live in remote areas which are far from financial institutions including BMT, this study shows that most of the respondents 1,695 (63.96\%) are living more than $2 \mathrm{~km}$ from BMT. Respondents who live near to BMT have a lower incidence of credit rationing occurrence.

Furthermore, $34.19 \%$ respondents had around 3-5 years of savings and $34.60 \%$ respondents more than 5 years of savings. Finally, 2,218 respondents $(83.70 \%)$ had access to previous financing, while only 242 respondents $(16.30 \%)$ had no access to previous financing. The frequency of credit rationing incidence is lower for respondents who had access to previous financing than for respondents who had no access to previous financing. Table 5 shows the demographics of the respondents and its relation to credit rationing:

Table 5.

Demographic of the Respondents and Its Relation to Credit Rationing

\begin{tabular}{|c|c|c|c|c|c|c|}
\hline Variable & & $\begin{array}{c}\text { Fully } \\
\text { funding }\end{array}$ & $\begin{array}{c}\text { Completely } \\
\text { rejected }\end{array}$ & $\begin{array}{l}\text { Partially } \\
\text { funding }\end{array}$ & Total & Percentage \\
\hline \multirow{3}{*}{ Gender } & Male & 726 & 10 & 270 & 1,006 & 37.96 \\
\hline & Woman & 1,178 & 41 & 425 & 1,644 & 62.04 \\
\hline & & 1,904 & 51 & 695 & 2,650 & \\
\hline \multirow{3}{*}{ Having Salary } & Yes & 897 & 28 & 311 & 1,236 & 46.64 \\
\hline & No & 1,007 & 23 & 384 & 1,414 & 53.36 \\
\hline & & 1,904 & 51 & 695 & 2,650 & \\
\hline \multirow{6}{*}{ Monthly Income } & Under $\$ 100$ & 480 & 26 & 234 & 740 & 27.92 \\
\hline & $\$ 100-\$ 150$ & 1,063 & 13 & 253 & 829 & $31.28 \%$ \\
\hline & $\$ 151-\$ 500$ & 195 & 9 & 178 & 882 & $33.28 \%$ \\
\hline & $\$ 501-\$ 1500$ & 119 & 3 & 24 & 146 & $5.51 \%$ \\
\hline & $\begin{array}{l}\text { More than } \\
\$ 1500 \\
\end{array}$ & 47 & 0 & 6 & 53 & $2.00 \%$ \\
\hline & & 1,904 & 51 & 695 & 2,650 & \\
\hline \multirow{3}{*}{ Head of household } & Yes & 854 & 24 & 297 & 1,175 & $44.34 \%$ \\
\hline & No & 1,050 & 27 & 398 & 1,475 & $55.66 \%$ \\
\hline & & 1,904 & 51 & 695 & 2,650 & \\
\hline \multirow{3}{*}{$\begin{array}{l}\text { Family generation } \\
\text { in the village }\end{array}$} & $0-3$ & 1,195 & 19 & 411 & 1,625 & $61.32 \%$ \\
\hline & $>3$ & 709 & 32 & 284 & 1,025 & $38.68 \%$ \\
\hline & & 1,904 & 51 & 695 & 2,650 & \\
\hline \multirow{5}{*}{$\begin{array}{l}\text { Years of formal } \\
\text { education }\end{array}$} & None & 159 & 16 & 90 & 265 & $10.00 \%$ \\
\hline & 1-6 years & 364 & 13 & 114 & 491 & $18.53 \%$ \\
\hline & 7-9 years & 519 & 11 & 189 & 719 & $27.13 \%$ \\
\hline & $>9$ years & 862 & 11 & 302 & 1,175 & $44.34 \%$ \\
\hline & & 1,904 & 51 & 695 & 2,650 & \\
\hline \multirow{4}{*}{$\begin{array}{l}\text { Relatives in the } \\
\text { village }\end{array}$} & None & 524 & 23 & 190 & 737 & $27.81 \%$ \\
\hline & $1-3$ & 780 & 15 & 299 & 1,094 & $41.28 \%$ \\
\hline & $>3$ & 600 & 13 & 206 & 819 & $30.91 \%$ \\
\hline & & 1,904 & 51 & 695 & 2,650 & \\
\hline
\end{tabular}


Table 5.

Demographic of the Respondents and Its Relation to Credit Rationing

\begin{tabular}{llccccc}
\hline Variable & & $\begin{array}{c}\text { Fully } \\
\text { funding }\end{array}$ & $\begin{array}{c}\text { Completely } \\
\text { rejected }\end{array}$ & $\begin{array}{c}\text { Partially } \\
\text { funding }\end{array}$ & Total & Percentage \\
\hline \multirow{2}{*}{$\begin{array}{l}\text { Distance from } \\
\text { house to BMT }\end{array}$} & $0-2 \mathrm{~km}$ & 705 & 21 & 229 & 955 & $36.04 \%$ \\
\hline \multirow{2}{*}{$>2 \mathrm{~km}$} & 1,199 & 30 & 466 & 1,695 & $63.96 \%$ \\
\hline \multirow{3}{*}{ Years of savings } & & 1,904 & 51 & 695 & 2,650 & \\
\cline { 2 - 7 } & $0-2$ years & 623 & 23 & 181 & 827 & $31.21 \%$ \\
\cline { 2 - 7 } & $3-5$ years & 605 & 16 & 285 & 906 & $34.19 \%$ \\
\hline & $>5$ years & 676 & 12 & 229 & 917 & $34.60 \%$ \\
\hline \multirow{2}{*}{$\begin{array}{l}\text { Access to Previous } \\
\text { financing }\end{array}$} & Yes & 1,904 & 51 & 695 & 2,650 & \\
\hline & No & 1,662 & 32 & 524 & 2,218 & $83.70 \%$ \\
\hline
\end{tabular}

A multinomial logistic approach is used to answer this question since this approach can facilitate multi-categorical dependent variables (completely rejected, partially funding and fully funding) that are considered in this model. 'A full funding' is used as the reference category in the dependent variable. The first step is to test the fitness of the model using a likelihood ratio and continues by measuring the strength between variables in the model using pseudo r-square. Moreover, a classification accuracy matrix is used to show the comparison between predicted and actual rating classified by the multinomial logistic model. Finally, model specification using multinomial logistics is used to test the relationship between dependent and independent variables.

\subsubsection{Model Fitting Information}

Several steps are conducted to measure the goodness-of-fit of the model. First, testing the model fitness uses a likelihood ratio test. Then, pseudo r-square is used to measure the strength between variables followed by classification accuracy. Table 6 shows the model fitting information of socio-demographic determinants of credit rationing.

Table 6.

Goodness-of-fit, Pseudo r-square and Classification Accuracy of the Socio-Demographic Determinants of Credit Rationing

\begin{tabular}{lcccc}
\hline \multirow{2}{*}{$\begin{array}{l}\text { Model Fitting Information and } \\
\text { Pseudo r-square }\end{array}$} & \multicolumn{2}{c}{$\begin{array}{c}\text { Model Fitting } \\
\text { Criteria }\end{array}$} & \multicolumn{2}{c}{ Likelihood Ratio tests } \\
\cline { 2 - 5 } & $\mathbf{- 2 \text { Log Likelihood }}$ & Chi-Square & Df & Sig. \\
\hline Intercept only & 3.451 & & 36 & $0.000^{* * *}$ \\
\hline Final & 3.181 & 270 & 0.097 \\
\hline \multirow{2}{*}{\begin{tabular}{l} 
Pseudo R-Square \\
\cline { 2 - 5 } $\begin{array}{l}\text { Overall Percentage of logistic } \\
\text { classification accuracy }\end{array}$
\end{tabular}} & Cox and Snell & 0.132 \\
\hline
\end{tabular}

Note: $\left({ }^{* * *}\right)$ indicates significant at 1 percent 


\section{(i) Likelihood ratio test}

Chi-square is used to test the model fit. Chi-square measures the difference between the observed and the fitted value. Chi-square is derived from the likelihood ratio (LR) on which it is calculated from -2(maximized value of the likelihood function under the null hypothesis) - -2(the maximized value of fitted model) (Hosmer and Lemeshow, 2000). In this model, the LR chi square is $3,451-3,181=270$. The chi-square test $(\mathrm{Q}<=.05)$ means that we reject the null hypothesis. It means that the independents make a difference in predicting the dependent in logistic regression. Therefore, the model is fit.

\section{(ii) Pseudo r-square}

Pseudo r-square are approximately equivalent when the probability of an event is small (Mittlböck and Heinzl, 2001). Hair, et al. (1995) found that $\mathrm{R}^{2}$ tend to be low in the case of large samples and cross-sectional data. Pseudo r-square is sensitive to sample size, which allows this measurement to find very small differences that are statistically significant when the sample size becomes large. The model also shows small pseudo r-square. However, none of the statistics tests has a percentage of variance explained interpretation and should not be reported in such terms (Arundina, 2015).

\section{(iii) Classification accuracy}

A classification accuracy table concludes the result of a fitted logistic regression (Hosmer and Lemeshow, 2000). However, an accurate or inaccurate classification does not address the criteria of goodness-of-fit because the distances between observed and expected values are unsystematic and within the variation of the model. It is only a supplement to the rigorous methods of assessment of fit. SPSS uses 50 per cent as the cut-off rate (Papias and Ganesan, 2009), which shows that the classification accuracy is above the benchmark level (50\%) and the classification accuracy is satisfied.

\subsubsection{Model Specification}

To generate the model specification, the odds ratio is used in multinomial regression. It is a measure of association which is widely used to approximate how much more likely (or unlikely) it is for the outcome to be present among those with $x=1$ than among those with $x=0$. For example, the odds are nonnegative with a value more than 1 , which means that a success is more likely than a failure. When odds $=4.0$, a success is four times as likely as a failure. The probability of success is 0.8 and failure 0.2. Therefore, the odds equal 0.8/0.2=4.0. An odds ratio value more than 1 in a given direction represents stronger association (Agresti, 2007). Table 7 below shows the multinomial logistic result on socio-demographic determinants of credit rationing: 
Table 7.

Multinomial Logistic Result on Socio-demographic Determinants of Credit Rationing

\begin{tabular}{|c|c|c|c|c|}
\hline \multirow{2}{*}{ Variable } & \multirow{2}{*}{$\begin{array}{c}\begin{array}{c}\text { Y1 } \\
\text { (Completely } \\
\text { rejected) }\end{array} \\
\text { B }\end{array}$} & \multicolumn{3}{|c|}{ Y2 (partially funding) } \\
\hline & & $\operatorname{Exp}(\mathrm{B})$ & B & $\operatorname{Exp}(B)$ \\
\hline Intercept $(\beta)$ & $-18.297^{* * *}$ & & $-1.295^{* *}$ & \\
\hline Age (AGE) & $-0.030^{* *}$ & 0.971 & 0.002 & 1.002 \\
\hline Gender: Man (GEN) & $-0.992^{* *}$ & 0.371 & $0.226^{*}$ & 1.254 \\
\hline $\begin{array}{l}\text { Distance to the nearest BMT: } 0-2 \mathrm{~km} \\
\text { (PROXY) }\end{array}$ & -0.015 & 0.985 & $-0.181^{* *}$ & 0.835 \\
\hline Years of savings: 0-2 years (SAVYEAR ${ }_{1}$ ) & 0.214 & 1.239 & $-0.441^{* * *}$ & 0.644 \\
\hline Years of savings: $3-5$ years (SAVYEAR ${ }_{2}$ ) & 0.19 & 1.209 & 0.177 & 1.194 \\
\hline $\begin{array}{l}\text { Have positive account balance } \\
\text { (BALDEPO) }\end{array}$ & $-1.104^{* * *}$ & 0.332 & $-0.774^{* * *}$ & 0.461 \\
\hline Number of children: 0-2 (DEPEDENTS ${ }_{1}$ ) & $-0.837^{* *}$ & 0.433 & $0.509^{* *}$ & 1.663 \\
\hline Number of children 3-5 (DEPEDENTS ${ }_{2}$ ) & -0.648 & 0.523 & $0.596^{* *}$ & 1.814 \\
\hline Head of household (HOH) & 0.563 & 1.755 & $-0.228^{* *}$ & 0.796 \\
\hline Having salary (SAL) & $0.891^{* * *}$ & 2.438 & -0.044 & 0.957 \\
\hline Monthly income: under $100\left(\mathrm{INCOME}_{1}\right)$ & $18.019^{* * *}$ & 6.691 & $1.246^{* * *}$ & 3.475 \\
\hline Monthly income: 101-150 ( INCOME $_{2}$ ) & $17.353^{* * *}$ & 3.439 & $1.180^{* * *}$ & 3.255 \\
\hline Monthly Income: 151-500 (INCOME ${ }_{3}$ ) & $17.232^{* * *}$ & 3.045 & 0.643 & 1.903 \\
\hline Monthly income: 501-1500 (INCOME $\left.{ }_{4}\right)$ & $17.842^{* * *}$ & 5.604 & 0.408 & 1.504 \\
\hline $\begin{array}{l}\text { Years of formal education: none } \\
\left.\text { (EDUCYEAR })_{1}\right)\end{array}$ & $1.891^{* *}$ & 6.626 & $0.344^{* *}$ & 1.41 \\
\hline $\begin{array}{l}\text { Years of formal education: 1-6 years } \\
\text { (EDUCYEAR }{ }_{2} \text { ) }\end{array}$ & $1.143^{* *}$ & 3.137 & $-0.246^{* *}$ & 0.782 \\
\hline $\begin{array}{l}\text { Years of formal education: 7-9 years } \\
\left(\text { EDUCYEAR }_{3} \text { ) }\right.\end{array}$ & 0.693 & 2.000 & 0.041 & 1.042 \\
\hline $\begin{array}{l}\text { Access on the previous financing } \\
\text { (ACCESS) }\end{array}$ & $-2.1^{* * *}$ & 0.122 & $-0.545^{* * *}$ & 0.580 \\
\hline
\end{tabular}

Notes:

a. The reference category for dependent variable is fully funded

b. Age is continuous variable

c. The reference of categorical variable of gender (woman), distance $(>2 \mathrm{~km})$, savings years $(>5$ years), having positive account balance (no), number of children ( $>5$ ), head of household (no), having salary (yes), monthly income (>\$1500), years of formal education ( $>9$ years), access on the previous financing (no)

d. $\left(^{* * *}\right)$ indicates significant at 1 percent $\left({ }^{* *}\right)$ indicates significant at 5 percent; $\left(^{*}\right)$ indicates significant at 10 percent

\subsection{Analysis}

From Equation (1), it can be inferred that there are several significant variables that influence credit rationing, i.e., age, gender, positive balance on borrowers account, salary, monthly income, dependencies, years of formal education and access to a financing facility in previous year. Similarly, Equation (2) also shows that the variables are significant except for salary. In addition, proximity and years of savings are also found significant. Further discussion on the variables is included below: 


\section{(i) Age}

The first determinant of credit rationing is age (AGE). The results show that with a one percent increase in respondent age, the respondent's log-odds of getting completely rejected in financing will decrease 0.971 times. A unit increase in age (year) leads to a $(1 / 0.971=1.0298)$ likelihood of being fully funded.

This finding is aligned with Papias and Ganesan (2010) who found that younger borrowers would get lower acceptance in financing. Young borrowers are more consumptive in spending money compared with older borrowers who tend to be more careful in their spending. Moreover, an older age would increase the probability of access because older people can accumulate more wealth and control their resources. Age is also an indicator of good financing repayment (Khoi et al., 2013). However, an exception is for borrowers who are not within the productive age group (too old) who face declining volume rationing with increasing age (Weber and Mussoff, 2013). Therefore, the empirical findings between age and credit rationing confirm the hypothesis of the study stating that older age has a negative influence on credit rationing.

\section{(ii) Gender}

The second variable that is shown to be an important determinant of credit rationing is gender (GEN). The result shows that the probability of men being completely rejected for financing is 0.371 lower compared with women. Men are $(1 / 0.371=2.695)$ times more likely to be fully funded compared with women. It can be summarized that men have greater access to a full funding than women. In other words, the probability of women being completely rejected for financing is 2.695 (i.e. 1/0.371) times greater than men do. This finding concurs the arguments proposed by Mijid and Bernasek (2013) and Vitor et al. (2014) about the male group being recognized as those having greater access to credit compared with females especially from formal microfinance, such as a bank. The observation could be due to women having no experience relating to income generating activities; therefore, the creditors foresee that women borrowers would have difficulties repaying their debts (Fletschner, 2009).

However, the probability of women being partially funded in financing is 0.79744 times lower than men with lower statistical significance (at 10\%). Females are (1/0.79744) 1.254 times more likely to be funded than partially funded compared with males. Although the probability of woman having their requested financing completely rejected is greater than for men, men have higher partial funding than women. In the case of getting their requested financing a partial funding, the eligibility of women to get fully funding is more than that for men. This means that BMT must have more focus on giving funding to women in order to increase women's participation in the BMT. Therefore, it can be concluded that the hypothesis stating the negative effect on men of getting credit rationing occurrence is confirmed in the cases of completely rejected to fully funding, while, in the case of partially rationing, the findings do not confirm the hypothesis. 


\section{(iii) Dependents}

Number of dependents is also shown to be statistically significant as a determinant in credit rationing. The result from Equation (1) shows that the probability of respondents who have a low number of dependents being completely rejected for financing is 0.433 lower than for the respondents who have a high number of dependents. BOP respondents with few dependents are (1/0.433) 2.31 times more likely to be fully funded compared with a high number of dependents. Bao Duong and Izumida (2002) found that a family with more dependents would have more credit rationing problems. This is because they face difficulty even to feed themselves resulting in an expected bad repayment.

Moreover, the probability of respondents who have low dependencies to have partially funding in financing is 1.663 times and increase to 1.814 times if the respondents have higher dependencies. It means that the person who has higher dependencies is likely to face higher cases of partially funding. Zeller, 1994 also found the same situation of more credit rationing occurrence when borrowers have more dependants. It is concluded that the hypothesis stating that dependency has a positive influence on credit rationing occurrence is confirmed.

\section{(iv) Positive balance on savings account}

Savings in Islamic microfinance can be considered as collateral. Several BMTs do not ask for collateral from their borrowers but require savings for every financing. Vitor et al. (2014) found that a positive balance on the borrowers' savings account will enhance the probability of securing a loan in full (non-credit rationed). The results of this study show that respondents who have a positive savings account balance are less likely to have completely rejected in financing, with a probability 0.332 lower compared with respondents who do not have a positive account balance. The positive amount of savings will enhance creditworthiness (Dusuki, 2008; Vitor et al., 2014).

In the case of a partial funding in financing, respondents who had a positive savings account balance were less likely to get partial funding in financing with a probability 0.461 lower compared with respondents who did not have a positive account balance. Since savings serve as a collateral, a greater amount of savings will reduce the probability of credit rationing occurrence (Vitor et al., 2014). The empirical findings confirm the hypothesis of the study stating that a positive balance of savings has a negative influence on credit rationing occurrence.

\section{(v) Salary}

Salary is an indicator of ability to repay financing. From the result of the study, it can be inferred that respondents who do not have a salary are more likely to have completely rejected in financing, with a probability 2.438 times higher compared with respondents who have a salary. Borrowers who have a regular salary will face lower credit rationing than borrowers who do not have regular salary because they are perceived to have a steady source of income which will used to repay the financing (Duca and Rosenthal, 1991; Zeller, 1994; Khoi et al., 2013). 
However, such a result does not agree with Zeller (1994) who found an insignificant relationship between credit rationing and having salary. One of reasons for the difference is that several BMTs borrowers work as employers and receives a monthly salary. Therefore, having a salary has influenced creditrationing conditions. Since the previous hypothesis stated that having a salary has no influence on credit rationing, the empirical findings related to having a salary and credit rationing are not confirmed.

\section{(vi) Monthly income}

Monthly income is also a determinant of credit rationing in the BMT. The probability of respondents who had a low monthly income being completely rejected in financing is higher than for respondents who had a high monthly income according to the Equation (1). Moreover, the same condition also occurs in equation (2) that the probability of respondents who had a low monthly income being partially funding in financing is higher than for respondents who had a higher monthly income.

Monthly income is an indicator of repayment especially monthly repayment. In BMT, repayment will automatically be debited by BMT from the account of borrower with monthly income. The common sources of income of Muslims at the BOP come from small medium enterprise (SME) activities (Mirghani et al., 2011). The same condition also occurred in BMT. Therefore, SME activities must be supported in order to enhance their ability to repay. In conclusion, the empirical findings confirm the hypothesis of the study stating that higher monthly income has a negative influence on credit rationing occurrence.

\section{(vii) Year(s) of formal education}

Year(s) of formal education is also a significant variable that influences credit rationing. From the Equation (1), it can be inferred that respondents who have lower number of years of formal education are more likely to have completely rejected for financing compared with respondents who have more high years of formal education. The same direction is seen in Equation (2) that found that respondents who had fewer years of formal education tend to have a higher incidence of a partial funding compared with respondents who had a greater number of years of formal education.

Consequently, the more educated the person is, the easier it is for him to get financing. Years of formal education is an indicator of how well applicants are likely to handle credit rationing problem because they have more knowledge than those who are less educated (Duong and Izumida, 2002; Menkhoff and Rungruxsirivorn, 2011; Azzam et al., 2012; Togba, 2012; Papias and Ganesan, 2010; Jia, Heidhues, and Zeller, 2010; Cheng and Ahmed 2014). Thus, the findings confirm the hypothesis stating that there is a negative influence of years of formal education on credit rationing occurrence. 
(viii) Access to financing facility in the previous year

From the Equation (1), it can be inferred that the probability of respondents who have had access to previous financing being completely rejected in financing is 0.122 times lower compared with respondents who had no access to previous financing. It is summarized that respondents who had access to previous financing are 8.196 times more likely to get a full funding compared with respondents who had no access to previous financing. In addition, Equation (2) shows the same pattern, that the probability of respondents who had access to the previous financing being partially funded in financing is 0.580 times lower compared with respondents who had no access to the previous financing. It is concluded that the findings confirm the hypothesis that access to previous financing has a negative influence on credit rationing occurrence.

This finding is contrary to that of with Becchett and Pisani (2008) who said that it is easy to get a financing from microfinance, having no knowledge of borrower's previous track record. However, this type of case is not implemented in Islamic microfinance. A track record from previous financing is important as a measurement of character. A good track record means a good character. Reputation and background are the main attributes that indicate good repayment in Islamic microfinance (Obaidullah and Latiff, 2008). Since a good track record is important in Islamic microfinance, access to previous financing will reduce credit rationing occurrence.

\section{(ix) Proximity}

Proximity or the distance of a borrower's house from BMT is also a determinant of credit rationing. The result showed that respondents who lived less far away from BMT tend to get partially funding in financing with a probability 0.835 times lower compared with respondents who lived at a farther distance. Respondents who had to travel farther to BMT are $(1 / 0.835=1.197)$ more likely to be completely rejected compared with respondents who have to travel less distance to BMT. People who lived closer to BMT will have easier access to financing since it will reduce the cost of monitoring because it does not require BMT staff to take public transportation that would incur a cost (Carling and Lundberg, 2005). A greater risk will be faced by MFIs if they provide funding to distant borrowers (Carling and Lundberg, 2005). However, the finding does not confirm the hypothesis that proximity has no influence on credit rationing occurrence.

\section{(x) Years of savings}

Similar to the amount of savings, which conduct as collateral, years of savings, is a proxy for consumer loyalty and trust to microfinance? The result shows that the probability of respondents who had a lower number of years of savings being partially funding in financing requested is 0.644 times lower compared with those with a higher number of years of savings. This aligns with Zeller (1994) found a lower probability of being credit rationed if potential borrowers have more savings years because it increases their level of creditworthiness and is an indicator of a 
respondent's loyalty (Chiu et al., 2014). Finally, the hypothesis stating that years of savings has a negative influence on credit rationing occurrence is confirmed.

\section{CONCLUSION AND RECOMMENDATION}

\subsection{Conclusion}

The findings based on the socio-demographic determinant indicate that age, being woman, not having a positive account balance, not having a salary, having only a few years of formal education and not having access to previous financing yield a positive probability of being rejected, rather than fully funded. First, age is indicator of maturity. An older age indicates more readiness to repay financing from BMT. Moreover, women are categorized as "not having income" so they suffer more in terms of completely being rejected in financing than do man. A positive account balance is a symbol of loyalty as loyalty will increase the level of trustworthiness and enhance the possibility of getting financing granted. Meanwhile, salary means regular income per month that can be used to repay financing every month.

Besides, the same directions occurs in the probability of being partially funded to fully funded, except where gender is concerned in which men have more probability of getting partial funding than full funding. This finding is contrary to the case in completely rejected. Although women has more probability getting completely rejected in financing but their probability of getting partially funding is lower than fully funding compared with man. Additional variables in the case of partially rationing to fully funding are salary, proximity to BMT and years of savings. A higher salary indicates less chance of getting to get partially funding. Having a salary is an indicator of good repayment. Low proximity to BMT will reduce the cost of monitoring. Therefore, borrowers with low proximity have more probability of getting fully funding. Last, years of savings is an indicator of borrower's loyalty. Loyalty will increase trustworthiness. Trustworthy borrowers have more probability of getting a full funding than a partial funding.

\subsection{Recommendation}

This study is expected to solve possible credit-rationing problems for borrowers at BOP and highlight several policy recommendations. The policy recommendations of this study include:

a. Creating the eligibility standard of BOP borrowers to get financing.

As the standard of eligibility is important for BMT in the first financing proposal, it is recommended that BMT use eligibility as screening in the first financing proposal. The eligibility criterion will ensure that only the poor or very poor can participate in BMT financing (M. K. Hassan and Renteria-Guerrero, 1997). However, for the second financing proposal, BMT must screen through character. Character will replace the function of eligibility for the second or additional financing proposal. BMT should provide various financial products.

BMT must provide various financial products. Nowadays, people at BOP are more critical. They can choose a financial institution provider as they want. Many of commercial banks build and create channeling to the microfinance sector. If 
BMT stay with their previous products without any improvement, they will lose out in competition with others.

b. The government should have extra budget to support BMT

The government must support BMT in several ways. First, the government must have a budget to support BMT growth since the purpose of BMT is reducing poverty. The condition of lack of money to be distributed to people at BOP must be considered by the government.

A government intervention especially in the rural credit market is needed to provide access for the poor through leading credit institutions, producing financing programs, and subsidizing margin, together with several interventions (Jia, 2010). It is because eradicating poverty and hunger is under the government responsibility.

\section{REFERENCES}

Ademola, M. (2014). Islamic Development Bank's Microfinance Support Programme and the Growth of Small Scale Enterprises in Nigeria, 10(2), 98107. http://doi.org/10.3968/4260

Agier, I., \& Szafarz, A. (2013). Microfinance and Gender: Is There a Glass Ceiling on Loan Size? World Development, 42(May 2010), 165-181. http://doi.org/10.1016/j. worlddev.2012.06.016

Ahiawodzi, a K., \& Sackey, F. G. (2010). Determinants of Credit Rationing to the Private Sector in Ghana. African Journal of Business E Economic Research, 5(1), 23-49. http://doi.org/10.5897/AJBM09.462

Al-Azzam, M., Carter Hill, R., \& Sarangi, S. (2012). Repayment performance in group lending: Evidence from Jordan. Journal of Development Economics, 97(2), 404-414. http://doi.org/10.1016/j.jdeveco.2011.06.006

Ali, D. A., \& Deininger, K. (2014). Causes and Implications of Credit Rationing in Rural Ethiopia: The Importance of Zonal Variation. Journal of African Economies, 23(4), 493-527. http://doi.org/10.1093/jae/eju008

Arundina, T. (2015). Asset-Based Sukuk Rating Prediction: Towards Building Statistical and Data Mining Models. International Islamic University of Malaysia.

Awunyo-Vitor, D., Mahama Al-Hassan, R., Bruce Sarpong, D., \& Egyir, I. (2014). Agricultural credit rationing in Ghana: what do formal lenders look for? Agricultural Finance Review, 74(3), 364-378. http://doi.org/10.1108/AFR-012013-0004

Badan Pusat Statistik. (2014). Statistik Indonesia 2014. (S. S. Demografi, Ed.). Jakarta: Badan Pusat Statistik.

Bao Duong, P., \& Izumida, Y. (2002). Rural Development Finance in Vietnam: A Microeconometric Analysis of Household Surveys. World Development, 30(2), 319-335. http://doi.org/10.1016/S0305-750X(01)00112-7

Bharti, K., Sharma, V., Agrawal, R., \& Sengar, A. (2014). Marketer's Mindset: Key to Develop Bottom of the Pyramid Market. Procedia - Social and Behavioral Sciences, 133, 169-179. http://doi.org/10.1016/j.sbspro.2014.04.182 
Boehe, D. M., \& Cruz, L. B. (2013). Gender and Microfinance Performance: Why Does the Institutional Context Matter? World Development, 47, 121-135. http:// doi.org/10.1016/j.worlddev.2013.02.012

Carling, K., \& Lundberg, S. (2005a). Asymmetric Information and Distance: An Empirical Assessment of Geographical Credit Rationing. Journal of Economics and Business, 57(1), 39-59. http://doi.org/10.1016/j.jeconbus.2004.07.002

Carling, K., \& Lundberg, S. (2005b). Asymmetric information and distance: an empirical assessment of geographical credit rationing. Journal of Economics and Business, 57(1), 39-59. http://doi.org/10.1016/j.jeconbus.2004.07.002

Cheng, E., \& Ahmed, A. D. (2014). The demand for credit, credit rationing and the role of microfinance: Evidence from poor rural counties of China. China Agricultural Economic Review, 6(2), 295-315. http://doi.org/10.1108/CAER-072012-0076

D’Espallier, B., Guérin, I., \& Mersland, R. (2011). Women and Repayment in Microfinance: A Global Analysis. World Development, 39(5), 758-772. http://doi. org/10.1016/j.worlddev.2010.10.008

De Meza, D., \& Webb, D. (2000). Does Credit Rationing Imply Insufficient Lending? Journal of Public Economics, 78(3), 215-234. http://doi.org/10.1016/ S0047-2727(99)00099-7

Demirguc-Kunt, \& Klapper, L. (2012). Measuring Financial Inclusion: The Global Findex Database. World Bank Policy Research Paper, 6025.

Drakos, K., \& Giannakopoulos, N. (2011a). On the determinants of credit rationing: Firm-level evidence from transition countries. Journal of International Money and Finance, 30(8), 1773-1790. http://doi.org/10.1016/j.jimonfin.2011.09.004

Drakos, K., \& Giannakopoulos, N. (2011b). On the determinants of credit rationing: Firm-level evidence from transition countries. Journal of International Money and Finance, 30(8), 1773-1790. http://doi.org/10.1016/j.jimonfin.2011.09.004

Dubofsky, D. A. (1985). Capital Market Credit Rationing and Stock Risk. Southern Economic Journal, 52(1), 191-202.

Duca, J. V., \& Rosenthal, S. S. (1991). An empirical test of credit rationing in the mortgage market. Journal of Urban Economics, 29(2), 218-234. http://doi. org/10.1016/0094-1190(91)90016-Z

Dusuki, A. W. (2008). Banking for the Poor: the Role of Islamic Banking in Microfinance Initiatives. Humanomics, 24(1), 49-66. http://doi. org/10.1108/08288660810851469

Fararah, F. S., \& Al-Swidi, A. K. (2013). The Role of the Perceived Benefits on the Relationship between Service Quality and Customer Satisfaction: A Study on the Islamic Microfinance and SMEs in Yemen Using PLS Approach. Asian Social Science, 9(10), 18-37. http://doi.org/10.5539/ass.v9n10p18

Ferri, G., \& Murro, P. (2014). Do firm-bank "odd couples" exacerbate credit rationing? Journal of Financial Intermediation. http://doi.org/10.1016/j. jfi.2014.09.002

Fletschner, D. (2009). Rural Women's Access to Credit: Market Imperfections and Intrahousehold Dynamics. World Development, 37(3), 618-631. http://doi. org/10.1016/j.worlddev.2008.08.005 
Hsieh, S. H., Li, C. S., \& Lee, S. M. (2013). Logistic Regression with Outcome and Covariates Missing Separately or Simultaneously. Computational Statistics and Data Analysis, 66, 32-54. http://doi.org/10.1016/j.csda.2013.03.007

J. Verteramo Chiu, L., V. Khantachavana, S., \& G. Turvey, C. (2014). Risk Rationing and the Demand for Agricultural Credit: A Comparative Investigation of Mexico and China. Agricultural Finance Review, 74(2), 248-270. http://doi. org/10.1108/AFR-05-2014-0011

Jaffee, D. M., \& Russell, T. (1976). Imperfect Information , Uncertainty , and Credit Rationing. The Quarterly Journal of Economics, 90(4), 651-666.

Jia, X., Heidhues, F., \& Zeller, M. (2010a). Credit rationing of rural households in China. Agricultural Finance Review, 70(1), 37-54. http://doi. org/10.1108/00021461011042620

Jia, X., Heidhues, F., \& Zeller, M. (2010b). Credit rationing of rural households in China. Agricultural Finance Review, 70(1), 37-54. http://doi. org/10.1108/00021461011042620

Khoi, P. D., Gan, C., Nartea, G. V., \& Cohen, D. a. (2013). Formal and informal rural credit in the Mekong River Delta of Vietnam: Interaction and accessibility. Journal of Asian Economics, 26, 1-13. http://doi.org/10.1016/j.asieco.2013.02.003

Krejcie, R. V, \& Morgan, D. W. (1970). Determining Sample Size for Research Activities. Educational and Psychological Measurement, 30, 607-610.

Malhotra, N. K. (1999). Marketing Research: An Applied Orientation (3rd ed., Vol. 77). Englewood Cliffs: NJ: Prentice Hall.

Martins, F., \& Winkler, A. (2013). Foreign ownership in Latin American microfinance institutions: evidence and impact. Journal of Business Economics, 83(6), 665-702. http://doi.org/10.1007/s11573-013-0668-2

Mason, D. R. (2014). Who Gets What? Determinants of Loan Size and Credit Rationing Among Microcredit Borrowers: Evidence From Nicaragua. Journal of International Development, 90(February 2013), 77-90. http://doi.org/10.1002/ jid

Menkhoff, L., \& Rungruxsirivorn, O. (2011). Do Village Funds Improve Access to Finance? Evidence from Thailand. World Development, 39(1), 110-122. http:// doi.org/10.1016/j.worlddev.2010.09.002

Mijid, N., \& Bernasek, A. (2013). Gender and the credit rationing of small businesses. The Social Science Journal, 50(1), 55-65. http://doi.org/10.1016/j. soscij.2012.09.002

Mirghani, M., Mohammed, M., Bhuiyan, A. B., \& Siwar, C. (2011). Islamic Microcredit And Poverty Alleviation In The Muslim World : Prospects And Challenges. Australian Journal of Basic and Applied Sciences, 5(9), 620-626.

Mittlböck, M., \& Heinzl, H. (2001). A Note on R2 Measures for Poisson and Logistic Regression Models When Both Models are Applicable. Journal of Clinical Epidemiology, 54(1), 99-103. http://doi.org/10.1016/S0895-4356(00)00292-4

Moruf O, O., \& S, O. K. (2014). Cooperative Financing Method and Microfinance Banks in Nigeria: Modeling Relationship for Credit Delivery Efficiency. Journal of Emerging Trends in Economics and Management Sciences, 5(7), 67-72.

Mughal, Z. (2014). Poverty in Muslim World is Rapidly Increasing. Humanomics (Vol. 29). Retrieved from http://www.alhudacibe.com/imhd/news22.php 
Nieri, L. (2005). 2 Access to Credit : the Difficulties of Households.

Papias, M. M., \& Ganesan, P. (2009). Repayment Behaviour in Credit and Savings Cooperative Societies: Empirical and Theoretical Evidence from Rural Rwanda. International Journal of Social Economics, 36(5), 608-625. http:/doi. org/10.1108/03068290910954059

Papias, M. M., \& Ganesan, P. (2010a). Financial services consumption constraints: Empirical evidence from Rwandan rural households. Journal of Financial Services Marketing, 15(2), 136-159. http://doi.org/10.1057/fsm.2010.11

Papias, M. M., \& Ganesan, P. (2010b). Financial services consumption constraints: Empirical evidence from Rwandan rural households. Journal of Financial Services Marketing, 15(2), 136-159. http://doi.org/10.1057/fsm.2010.11

Peng, C. J., Lee, K. L., \& Ingersoll, G. M. (2002). An Introduction to Logistic Regression Analysis and Reporting. The Journal of Educational Research but, 2(1), 3-14.

Petrick, M. (2004). Farm Investment, Credit Rationing, and Governmentally Promoted Credit Access in Poland: A Cross-Sectional Analysis. Food Policy, 29(3), 275-294. http://doi.org/10.1016/j.foodpol.2004.05.002

Prahalad, C. K., \& Hart, S. L. (2002). The Fortune at the Bottom of the Pyramid. Booz Allen Hamilton Inc.

Rahman, A. R. A. (2010). Islamic microfinance: an ethical alternative to poverty alleviation. Humanomics, 26(4), 284-295. http://doi. org/10.1108/08288661011090884

Rokhman, W. (2013). Baitul mal wat tamwil (bmt) and poverty empowerment. Qudus International Journal of Islamic Studies, 1(2), 181-196.

Rulindo, R. (2012). Assessing The Impact Of Islamic Microfinancing On Clients' Income And Poverty Status With Reference to Clients' Spirituality And Religiousity in Jakarta, Indonesia. IIUM.

Saad, N., \& Anuar, A. (2014). "Cash Waqf" and Islamic Microfinance. In Islam and Civilizational Renewal: The Global Financial Crisi (pp. 337-394). Pluto Journals.

Shankar, S. (2013). Financial Inclusion in India: Do Microfinance Institutions Address Access Barriers? Financial Inclusion: Importance and Common Barriers. ACRN Journal of Entrepreneurship Perspectives, 2(1), 60-74.

Shaw, J. (2004). Microenterprise Occupation and Poverty Reduction in Microfinance Programs: Evidence from Sri Lanka. World Development, 32(7), 1247-1264. http://doi.org/10.1016/j.worlddev.2004.01.009

Stiglitz, J. E., \& Weiss, A. (1981). Credit Rationing in Markets with Imperfect Information. The American Economic Review, 71(3), 393-410.

Stiglitz, J. E., Weiss, A., \& Stiglitz, B. J. E. (1987). Credit Rationing: Reply. The American Economic Review, 77(1), 228-231.

Strauss, D. (1992). The Many Faces of Logistic Regression. The American Statistician, 46(4), 321-327. Retrieved from http://www.jstor.org/stable/2685327

Togba, E. L. (2012a). Microfinance and Households Access to Credit: Evidence from Côte d'Ivoire. Structural Change and Economic Dynamics, 23(4), 473-486. http://doi.org/10.1016/j.strueco.2012.08.002

Togba, E. L. (2012b). Microfinance and households access to credit: Evidence from Côte d'Ivoire. Structural Change and Economic Dynamics, 23(4), 473-486. http:// doi.org/10.1016/j.strueco.2012.08.002 
Turvey, C. G., He, G., Kong, R., Ma, J., \& Meagher, P. (2011). The 7 Cs of rural credit in China. Journal of Agribusiness in Developing and Emerging Economies, 1(2), 100-133. http://doi.org/10.1108/20440831111167146

Vasimalai, M. P., \& Narender, K. (2007). Microfinance for Poverty Reduction : The Kalanjiam Way. Economic and Political Weekly, 42(13), 1190-1195.

Verma, N., \& Anand Pathak, A. (2011). Using appreciative intelligence for ice breaking. Journal of Workplace Learning, 23(4), 276-285. http://doi. org/10.1108/13665621111128682

Zeller, M. (1994). Determinants of credit rationing: A study of informal lenders and formal credit groups in Madagascar. World Development, 22(12), 18951907. http://doi.org/10.1016/0305-750X(94)90181-3 
This page is intentionally left blank 